\title{
A cost-efficient method to assess carbon stocks in tropical peat soil
}

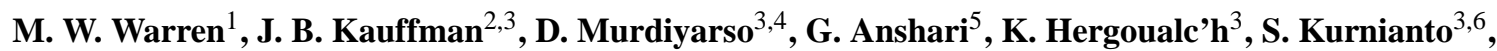

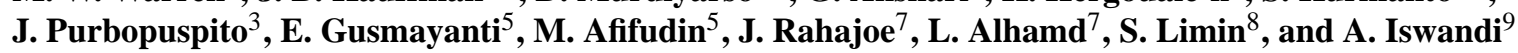 \\ ${ }^{1}$ USDA Forest Service, Northern Research Station, 271 Mast Rd., Durham NH 03824, USA \\ ${ }^{2}$ Oregon State University, Dept. of Fisheries and Wildlife, Nash Hall Rm 104, Corvallis OR, USA \\ ${ }^{3}$ Center for International Forestry Research, Jalan CIFOR, Situ Gede, Bogor Barat 16115, Indonesia \\ ${ }^{4}$ Bogor Agricultural University, Dept. of Geophysics and Meteorology, Jalan Meranti, Kampus IPB \\ Darmaga Bogor 16680, Indonesia \\ ${ }^{5}$ Universitas Tanjungpura, Center for Wetlands People and Biodiversity, Jalan Ahmad Yani, Pontianak 78124, \\ West Kalimantan, Indonesia \\ ${ }^{6}$ University of New Hampshire, Institute for the Study of Earth, Oceans and Space, Morse Hall 8, College Road, \\ Durham NH 03824, USA \\ ${ }^{7}$ Indonesian Institute of Sciences Research Center for Biology, Cibinong Science Center, Jalan, Raya Jakarta, Bogor Km 46, \\ Cibinong, West Java, Indonesia \\ ${ }^{8}$ CIMTROP, University of Palangka Raya, Kampus Tunjung Nyaho, Central Kalimantan 73111, Indonesia \\ ${ }^{9}$ Bogor Agricultural University, Dept. of Soil Science and Land Management, Laboratory of Soil Biotechnology, \\ Jalan Meranti, Kampus IPB Darmaga Bogor 16680, Indonesia
}

Correspondence to: M. W. Warren (mwwarren@fs.fed.us)

Received: 20 March 2012 - Published in Biogeosciences Discuss.: 14 June 2012

Revised: 18 October 2012 - Accepted: 24 October 2012 - Published: 14 November 2012

\begin{abstract}
Estimation of belowground carbon stocks in tropical wetland forests requires funding for laboratory analyses and suitable facilities, which are often lacking in developing nations where most tropical wetlands are found. It is therefore beneficial to develop simple analytical tools to assist belowground carbon estimation where financial and technical limitations are common. Here we use published and original data to describe soil carbon density $\left(\mathrm{kgC} \mathrm{m}^{-3}\right.$; $\left.\mathrm{C}_{\mathrm{d}}\right)$ as a function of bulk density $\left(\mathrm{gC} \mathrm{cm}^{-3} ; B_{\mathrm{d}}\right)$, which can be used to rapidly estimate belowground carbon storage using $B_{\mathrm{d}}$ measurements only. Predicted carbon densities and stocks are compared with those obtained from direct carbon analysis for ten peat swamp forest stands in three national parks of Indonesia. Analysis of soil carbon density and bulk density from the literature indicated a strong linear relation$\operatorname{ship}\left(\mathrm{C}_{\mathrm{d}}=B_{\mathrm{d}} \times 495.14+5.41, R^{2}=0.93, n=151\right)$ for soils with organic $\mathrm{C}$ content $>40 \%$. As organic $\mathrm{C}$ content decreases, the relationship between $C_{\mathrm{d}}$ and $B_{\mathrm{d}}$ becomes less predictable as soil texture becomes an important determinant of $\mathrm{C}_{\mathrm{d}}$. The equation predicted belowground $\mathrm{C}$ stocks to within $0.92 \%$ to $9.57 \%$ of observed values. Average
\end{abstract}

bulk density of collected peat samples was $0.127 \mathrm{~g} \mathrm{~cm}^{-3}$, which is in the upper range of previous reports for Southeast Asian peatlands. When original data were included, the revised equation $\mathrm{C}_{\mathrm{d}}=B_{\mathrm{d}} \times 468.76+5.82$, with $R^{2}=0.95$ and $n=712$, was slightly below the lower $95 \%$ confidence interval of the original equation, and tended to decrease $C_{d}$ estimates. We recommend this last equation for a rapid estimation of soil C stocks for well-developed peat soils where C content $>40 \%$.

\section{Introduction}

Tropical wetland forests containing organic soils - mangroves and freshwater peat swamps - are significant global carbon (C) stores (Donato et al., 2011). Page et al. (2011) estimated 88.6 $\mathrm{PgC}$ are stored in tropical peatlands worldwide, with $68.5 \mathrm{PgC}(77 \%)$ occurring in Southeast Asia. Similarly, Donato et al. (2011) estimated mangroves may contain up to $20 \mathrm{PgC}$ globally. Tropical wetland forests are susceptible to large-scale $\mathrm{C}$ losses, due to their high $\mathrm{C}$ storage and 
rapid rates of deforestation (Langner et al., 2007; Miettinen and Liew, 2010a, b). Of further concern is the vulnerability of tropical wetland $\mathrm{C}$ pools exacerbated by predicted consequences of global climate change: ENSO-related droughts and subsequent fires, altered precipitation patterns, increasing frequency and severity of tropical cyclones and sea level rise (Ellison and Stoddart, 1991; Li et al., 2007; Field et al., 2009).

Tropical wetlands are also well known for their numerous ecosystem services and unique biodiversity. Because of these values and vulnerabilities, tropical wetland forests are of particular interest in climate change mitigation strategies such as reduced emissions from deforestation and degradation (REDD+; Murdiyarso et al., 2010; Hergoualc'h and Verchot, 2011). However, data deficiencies preclude the rigorous $\mathrm{C}$ accounting necessary for the successful implementation of REDD+ activities in tropical wetlands (IPCC, 2006). There is a pressing need for accurate $\mathrm{C}$ assessments in tropical wetland ecosystems to establish baseline $\mathrm{C}$ stocks, and real and potential $\mathrm{C}$ losses from disturbance.

Belowground carbon pools of tropical wetlands are quite high. Chimner and Ewel (2005) estimated 330$775 \mathrm{Mg} \mathrm{ha}^{-1}$ of belowground peat $\mathrm{C}$ for forests on Kosrae, and $1077 \mathrm{MgCha}^{-1}$ were reported for riverine peat forests over shallow peat horizons in Tanjung Puting, Indonesia (Murdiyarso et al., 2009). Jaenicke et al. (2008) estimated up to $3130 \mathrm{MgC} \mathrm{ha}^{-1}$ for the Sebangau peat formation in Indonesia, and Page et al. (2011) calculated a global average of $2009 \mathrm{MgC} \mathrm{ha}^{-1}$ for all tropical peatlands. By comparison, the soil carbon pools of upland tropical forests have been shown to range from $76 \mathrm{MgCha}^{-1}$ in dry forests with shallow soils $<60 \mathrm{~cm}$ in depth to about $268 \mathrm{MgCha}^{-1}$ in wet forests (Kauffman et al., 2009). Kauffman et al. (2009) reported total ecosystem $\mathrm{C}$ pools (aboveground + belowground pools) in upland Neotropical forests ranging from $141 \mathrm{Mg} \mathrm{ha}^{-1}$ in tropical dry forest to $571 \mathrm{Mg} \mathrm{ha}^{-1}$ in lower montane moist forests.

Land conversion on peatlands results in immediate massive $\mathrm{C}$ fluxes to the atmosphere due to drainage, deforestation and burning followed by longer-term oxidative losses contingent on hydrological conditions (Hooijer et al., 2010; Murdiyarso et al., 2010; Hergoualc'h and Verchot, 2011). Murdiyarso et al. (2010) estimated $25 \%$ of all $\mathrm{C}$ emissions from converting peat forest to industrial plantations (a dominant land use transition of tropical peatlands in Indonesia; Miettinen et al., 2012) occur from initial burning to clear land. Each year, large areas of peatland burn throughout Indonesia with fire recurring frequently in areas where peat is drained and degraded. During the unusually severe fire season of 1997 , drought conditions prompted opportunistic and uncontrolled burning which eventually affected over 2 Mha of wetland ecosystems throughout Indonesia, resulting in $\mathrm{C}$ losses commensurate with the $1.5 \mathrm{PgC}$ average annual flux from global land use change from 1990-2005 (Taconni, 2003; Le Quéré et al., 2009; Page et al., 2002; Langmann and Heil, 2004).
The large estimates of greenhouse gas emissions from altered tropical wetlands are of particular concern considering their rapid deforestation rates (Langner et al., 2007; Miettinen and Liew, 2010a, b). Langner et al. (2007) estimated that annual deforestation rates of mangroves and peat swamp forests on the island of Borneo were $7.92 \%$ and $2.24 \%$ (respectively) for the years 2002-2005, and Miettinen et al. (2011) reported a similar average annual peat swamp forest deforestation rate of $2.2 \%$ between 2000 and 2010 for insular Southeast Asia. In addition, Miettinen and Liew (2010b) estimated that half of the peat swamp forest area mapped in peninsular Malaysia, Borneo and Sumatra in 1990 had been converted to other land uses by 2008. All of these studies indicate that deforestation rates of wetland forests exceed that of any other forest type, implying largescale $\mathrm{C}$ emissions from land use change.

The uncertainties of ecosystem carbon stocks of tropical wetlands and emissions from land cover change as well as their difficulties in measurement are well known and recognized, and limit the accuracy of large-scale $\mathrm{C}$ stock and flux estimates for tropical wetlands (Hergoualc'h and Verchot, 2011). The widespread estimation of soil C stocks in tropical wetlands has been partly limited by the lack of access to suitable technical facilities and analytical equipment in remote developing areas. Induction furnace $\mathrm{C}$ analyzers are costly and depend on infrastructure and the availability of consumables to be run properly. Other methods of $\mathrm{C}$ analysis (such as Walkley-Black wet combustion and loss on ignition; LOI) are only semi-quantitative and lose precision when soil organic matter content is very high (Nelson and Sommers, 1982). Therefore, it is beneficial to derive simple analytical tools to partially overcome these challenges and provide a method to accurately estimate soil $\mathrm{C}$ storage without the need for complicated laboratory analyses.

Soil carbon stocks (per unit area) are estimated as the product of carbon concentration (\%C), bulk density $\left(\mathrm{g} \mathrm{cm}^{-3}\right)$, and soil volume $\left(\mathrm{m}^{-3}\right)$. These properties cannot be measured directly from satellite or airborne sensors, and therefore rely on intensive field sampling for data acquisition. Reliable depth estimates require numerous point measurements in the field, which do not exist for most areas, and many large-scale peat volume estimates use average depths from point samples without spatial interpolation or area-weighted means (but see Jaenicke et al., 2008). Measurements of bulk density and $\mathrm{C}$ concentration require careful sample extraction in the field and subsequent analysis using laboratory equipment. Bulk density and $\mathrm{C}$ concentration can vary spatially and throughout the vertical peat profile, resulting in complicated three-dimensional $\mathrm{C}$ storage patterns (Page et al., 2004). Therefore, multiple measurements of carbon concentration and bulk density from samples taken at various depths in the soil profile are needed to accurately determine the soil carbon stocks (Donato et al., 2011; Kauffman et al., 2011; Murdiyarso et al., 2010). 
Considering the technical hurdles that must be overcome to successfully measure and monitor belowground $\mathrm{C}$ pools in tropical wetlands, it would be useful to develop analytical approaches using well-correlated soil properties for localized and rapid, yet accurate, $\mathrm{C}$ assessments. Here, we use published and original data to determine the relationship of volumetric $\mathrm{C}$ density and bulk density for tropical peat soils. Our objective was to determine if a universal equation developed from more easily sampled variables of bulk density and peat depth is sufficient to estimate peat $\mathrm{C}$ stocks rapidly and accurately. If so, the method could be useful for estimating soil carbon in the framework of wetland forest carbon inventories and greenhouse gas mitigation programs.

\section{Methods}

Data for this study were compiled from peer-reviewed research articles, previous reviews, a doctoral thesis, and data that we collected from Indonesian peat forests (Table 1). The following variables were assembled: sample region, site and/or peat type, sample depth, carbon content (\%C), bulk density and total carbon mass of the peat layers. Data were only included if carbon content was determined by induction furnace methods. Elemental $\mathrm{C}$ analysis is considered the most accurate and avoids error associated with other semiquantitative methods of $\mathrm{C}$ determination including loss on ignition (LOI) or wet combustion (Kauffman and Donato, 2012). Values for carbon density $\left(C_{d} ; \mathrm{kgC} \mathrm{cm}^{-3}\right.$ soil) were included from the original data sources or calculated from published bulk densities and $\mathrm{C}$ contents.

Original data included in this study were collected using modified methods described by Kauffman et al. (2011) and Kauffman and Donato (2012). Peat samples were taken as part of an extensive survey of ecosystem $\mathrm{C}$ stocks in one hectare peat swamp forest stands throughout Indonesia including four sites at Danau Sentarum National Park (W. Kalimantan Province), four sites at Sabangau Natural Laboratory for Peat Swamp Forest (NLPSF; C. Kalimantan Province), and two sites at Berbak National Park (Jambi Province, Sumatra). At each of these sites three to six peat cores were extracted from $10 \mathrm{~m}$ diameter subplots established along $250 \mathrm{~m}$ transects using a Russian peat sampler (Jowsey, 1966). A $250 \mathrm{~m}$ transect was used as it was also the axis of a $250 \mathrm{~m} \times 40 \mathrm{~m}$ (1 ha) vegetation sampling plot. Minimum distance between peat cores was $50 \mathrm{~m}$, and between sites was $700 \mathrm{~m}$. Transect positions were generally orientated perpendicular to the edge of the peat formation. Peat samples taken from the organic-mineral boundary horizons were not included in the analysis, and distinguished as transitional soil horizons in the field by the presence of mineral soil mixing with the organic peat fraction and associated changes in texture and color.

In Danau Sentarum National Park, transects were located in the vicinity of the Hutan Nung $\left(0^{\circ} 46^{\prime} 20^{\prime \prime} \mathrm{S}, 112^{\circ} 07^{\prime} 00^{\prime \prime} \mathrm{E}\right)$ forest, accessible from Bukit Tekenang research station. Peat cores were taken at 0,100 , and $150 \mathrm{~m}$ points along transects. Peat samples were removed from the auger in $10 \mathrm{~cm}$ increments and sampled until underlying mineral substrate was reached. Four sites were sampled, with 3 cores per site (12 peat sample cores). Peat depth ranged from 2.1 to $12.7 \mathrm{~m}$ across the four sites, and a total of 434 peat samples were collected. Peat samples were transported to the soil laboratory at Tanjungpura University within one week for drying at $70^{\circ} \mathrm{C}$ and weighing for bulk density determination.

In the Sabangau and Berbak sites, $5 \mathrm{~cm}$ peat samples were taken from the midpoint of $0-15,15-30,30-50,50-100$, $100-300 \mathrm{~cm}$ depth increments, and every $50 \mathrm{~cm}$ thereafter for depths $>300 \mathrm{~cm}$ (Kauffman et al., 2011). Sampling was biased to the upper peat layers that are most likely impacted by land uses (Ballhorn et al., 2009; Anshari et al., 2010). Samples were transferred directly to a $70^{\circ}$ drying oven as soon as possible, usually within $72 \mathrm{~h}$.

Peat samples from Sabangau were collected within the NLPSF $\left(2^{\circ} 19^{\prime} 00^{\prime \prime} \mathrm{S}, 113^{\circ} 54^{\prime} 29^{\prime \prime} \mathrm{E}\right)$ managed by the Centre for the International Cooperation in Sustainable Management of Tropical Peatlands (CIMTROP) based at the University of Palangka Raya. Sampling design was the same as for Danau Sentarum, with four transects sampled and peat cores extracted at 0,100 , and $250 \mathrm{~m}$ resulting in 12 cores ranging from 1.9 to $4.2 \mathrm{~m}$ depth. A total of 104 peat samples were collected from the Sabangau NLPSF, with 8 samples from the mineral-organic interface, not included in this analysis.

In Berbak National Park, two transects were sampled in the forest area surrounding a field camp managed by the Zoological Society of London's Sumatran tiger conservation program. In one transect, peat cores were taken every $50 \mathrm{~m}$ resulting in 6 cores to assess the scale of variation along the $250 \mathrm{~m}$ transect. A total of 9 peat cores were extracted from Berbak National Park ranging from 4.1 to $6.2 \mathrm{~m}$ in depth, with a total 70 peat samples collected. Two samples were from the organic-mineral transition horizon and excluded from analysis.

Dried peat samples from all sites were ground, homogenized, and analyzed for $\mathrm{C}$ concentration using a LECO TruSpec induction furnace $\mathrm{C}$ analyzer (LECO Corporation, St. Joseph MI, USA).

The linear equation describing carbon density $\left(C_{d}\right)$ as a function of dry bulk density $\left(B_{\mathrm{d}}\right)$ was determined with linear regression using data collated from the literature review. Since $\mathrm{C}_{\mathrm{d}}$ is the product of $B_{\mathrm{d}}$ and $\mathrm{C}$ concentration, a linear relationship was expected with a slope equal to the average $\mathrm{C}$ concentration of the peat samples and an intercept of 0 , assuming the $\mathrm{C}$ fraction of peat varies randomly with bulk density. Although there is a negative relationship between soil organic $\mathrm{C}$ concentration and bulk density for mineral soils, this relationship was not expected for organic peat soils since mineral fractions are extremely low. To validate the model and provide proof of concept, $\mathrm{C}_{\mathrm{d}}$ was predicted for each sample collected in the field using measured bulk density values 
Table 1. Source and locations of data used for this study.

\begin{tabular}{|c|c|c|c|}
\hline Source & Country & Region & Notes \\
\hline Anshari et al. (2010) & Indonesia & W. Kalimantan & $\begin{array}{l}\text { Includes coastal and inland peat forests, logged peat forest, industrial timber, } \\
\text { community agriculture, and oil palm plantations. Chemical analysis performed up to } \\
200 \mathrm{~cm} \text { depth. }\end{array}$ \\
\hline Brady (1997) & Indonesia & $\begin{array}{l}\text { Sumatra: S. } \\
\text { Sumatra and Riau }\end{array}$ & $\begin{array}{l}\text { Three primary peat forest sites. Data for upper and lower acrotelm layers, } 0-40 \mathrm{~cm} \\
\text { depth. }\end{array}$ \\
\hline $\begin{array}{l}\text { Kauffman et al. (2011); } \\
\text { Murdiyarso et al. (2009) }\end{array}$ & $\begin{array}{l}\text { Indonesia/ } \\
\text { Federated States } \\
\text { of Micronesia }\end{array}$ & $\begin{array}{l}\text { C. Kalimantan/ } \\
\text { Kosrae }\end{array}$ & $\begin{array}{l}\text { C. Kalimantan: riverine peat swamp forests characterized by shallow }(<1 \mathrm{~m}) \text { peats, } \\
\text { higher } B_{\mathrm{d}}\left(\text { mean }=460 \mathrm{~kg} \mathrm{~m}^{-3}\right) \text { and low } \% \mathrm{C}(25.4 \%) \text {. Kosrae: coastal peat forest } \\
\text { sampled in five locations, also with } \mathrm{C} \text { content generally lower than } 50 \% \text {. Sample } \\
\text { depths to ca. } 200 \mathrm{~cm} \text {. }\end{array}$ \\
\hline Lähteenoja et al. (2009) & Peru & $\begin{array}{l}\text { Lowland } \\
\text { Peruvian Amazon }\end{array}$ & $\begin{array}{l}\text { Three floodplain sites including open peatland, palm swamp forest, peat forest. } \\
\text { Sample depths up to } 570 \mathrm{~cm} \text {. }\end{array}$ \\
\hline Melling et al. (2005) & Malaysia & Sarawak & Includes three sites: drained forest, sago, and oil palm plantations. \\
\hline Neuzil (1997) & Indonesia & $\begin{array}{l}\text { C. Kalimantan } \\
\text { W. Kalimantan } \\
\text { Riau ( } 2 \text { sites })\end{array}$ & $\begin{array}{l}\text { Incremental data taken from one core per site. Peat thickness ranged from } 2.41 \text { to } \\
\text { about } 3.4 \mathrm{~m} \text {. }\end{array}$ \\
\hline Page et al. (2004) & Indonesia & C. Kalimantan & $\begin{array}{l}\text { Incremental data for a single continuous core to } 960 \mathrm{~cm} \text { depth. A single value for } \\
\text { depth } 0-90 \mathrm{~cm} \text { was derived using average profile } B_{\mathrm{d}} \text { reported in text and average } \% \mathrm{C} \\
\text { value } 0-90 \mathrm{~cm} \text {. }\end{array}$ \\
\hline Shimada et al. (2001) & Indonesia & C. Kalimantan & $\begin{array}{l}\text { Includes terrace, basin/domed, riverine, floodplain and marginal peatland. Also cites } \\
\text { data from Neuzil (1997) for Sumatran and W. Kalimantan sites. Values reported are } \\
\text { averages of normalized profile depth. }\end{array}$ \\
\hline This study & Indonesia & $\begin{array}{l}\text { W. Kalimantan } \\
\text { C. Kalimantan } \\
\text { Jambi, Sumatra }\end{array}$ & $\begin{array}{l}\text { Includes peat cores extracted from ten peat swamp forest sites across three national } \\
\text { parks of Indonesia. Peat depths ranged from } 1.75 \text { to } 12.7 \mathrm{~m} .597 \text { peat samples were } \\
\text { used to compare predicted and measured carbon density values and estimated C stocks }\end{array}$ \\
\hline
\end{tabular}

and the linear equation derived from literature review. The measured $\mathrm{C}_{\mathrm{d}}$ of each sample calculated from bulk density and $\mathrm{C}$ concentration was then compared with predicted values and the $95 \%$ confidence intervals of the linear model. As a final step, we compared carbon stocks $\left(\mathrm{MgC} \mathrm{ha}^{-1}\right)$ estimated from predicted and measured values of carbon density.

\section{Results}

A total of 151 values for bulk density, C density, and C concentration were available in the literature for tropical wetland soils and met our criteria (Table 1). Data included in the analysis span numerous sites, organic soil types, and land uses throughout Indonesia and three Peruvian sites. Published C contents ranged from 4.4 to $62.0 \%$, with a mean of $49.5 \%$. Bulk densities ranged from 0.030 to $0.565 \mathrm{~g} \mathrm{~cm}^{-3}$, with a mean of $0.130 \mathrm{~g} \mathrm{~cm}^{-3}$. Soils with lower C content $(<20 \%)$ and higher bulk densities $\left(>0.25 \mathrm{~g} \mathrm{~cm}^{-3}\right)$ were associated with mangroves and shallow peats which contain a high mineral fraction and are distinct from deeper, well-developed organic peat swamp soils with no detectable mineral fraction.

The relationship between $B_{\mathrm{d}}$ and $\mathrm{C}_{\mathrm{d}}$ for organic soils with $\mathrm{C}$ concentration exceeding $40 \%$ is described by the equation (Table 2):

$\mathrm{C}_{\mathrm{d}}=B_{\mathrm{d}} \times 495.14+5.41 ; R^{2}=0.93, p<0.001$,

where $\mathrm{C}_{\mathrm{d}}$ is $\mathrm{C}$ density $\left(\mathrm{kg} \mathrm{m}^{-3}\right)$ and $B_{\mathrm{d}}$ is dry bulk density $\left(\mathrm{g} \mathrm{cm}^{-3}\right)$. The equation to predict carbon density is applicable but limited to peat soils with low mineral content, typical of well-developed ombrotrophic peat swamp forests that do
Table 2. Parameters of the linear relationship $C_{\mathrm{d}}=B_{\mathrm{d}} \times a+b$ between dry bulk density $B_{\mathrm{d}}\left(\mathrm{g} \mathrm{cm}^{-3}\right)$ and carbon density $C_{\mathrm{d}}$ $\left(\mathrm{kg} \mathrm{m}^{-3}\right)$ derived from literature values (Eq. 1) and including field data from this study (Eq. 2) . Eq. (3) was calculated from log transformed data to correct heteroscedasticity. Equations valid for $\mathrm{C}$ concentration $>40 \%$.

\begin{tabular}{llrrrrr}
\hline & & & \multicolumn{4}{c}{$95 \%$ Confidence Interval } \\
& & df & Coefficient & Lower & Upper & $R^{2}$ \\
\hline Equation (1) & Intercept & 116 & 5.41 & 2.92 & 7.89 & 0.93 \\
& Slope & 116 & 495.14 & 471.11 & 519.17 & \\
Equation (2) & Intercept & 712 & 5.82 & 4.83 & 6.81 & 0.95 \\
& Slope & 712 & 468.76 & 461.05 & 476.47 & \\
Equation (3) & Intercept & 712 & 4.76 & 4.67 & 4.85 & 0.96 \\
& Slope & 712 & 476.82 & 476.1 & 477.53 & \\
\hline
\end{tabular}

not receive deposits of allochthonous sediments (Fig. 1). The clear relationship between $C_{\mathrm{d}}$ and $B_{\mathrm{d}}$ diminishes when soil $\mathrm{C}$ concentration falls below $40 \%$. As the mineral fraction of the soil increases, $C_{d}$ becomes less predictable as soil physical properties (such as clay content) play a larger role in determining carbon content. Organic soils with higher mineral content and lower C concentration $(<40 \%)$ frequently occur at the interface of peat and underlying mineral substrate, in shallower $(<60 \mathrm{~cm})$ peats, and in floodplains and estuaries where mineral alluvium is deposited periodically over organic material.

The equation that describes $C_{\mathrm{d}}$ as a function of $B_{\mathrm{d}}$ (Eq. 1) was used to predict $C_{d}$ values for 597 peat samples collected in the Danau Sentarum, Sabangau, and Berbak sites (Fig. 1). Using the equation to predict $C_{d}$ based upon $B_{d}$ derived from the literature (Eq. 1) resulted in overestimates of 

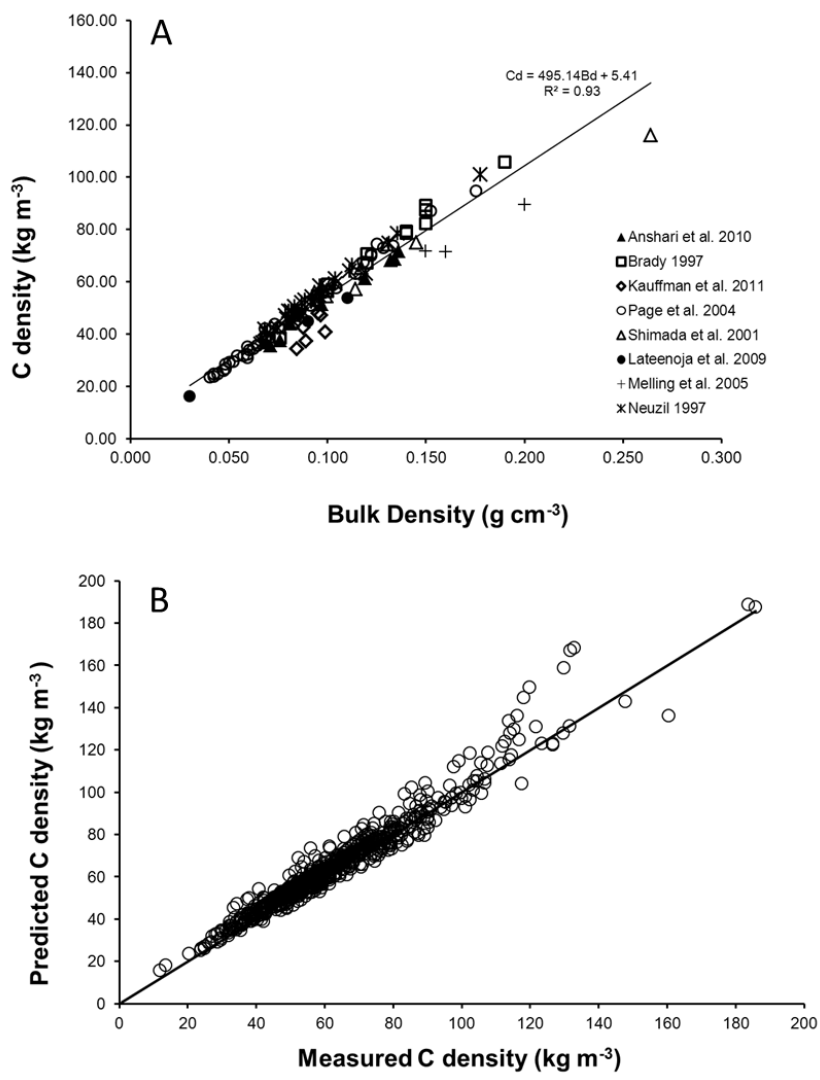

Fig. 1. (A) Linear relationship between $\mathrm{C}$ density and dry bulk density for peat soils $>40 \%$ derived from nine primary literature sources. (B) Predicted carbon density versus measured carbon density, with $1: 1$ line for 591 peat samples collected in this study.

$\mathrm{C}_{\mathrm{d}}$ for some samples (Fig. 1). Of the 597 samples that were classified as peat in the field, and close to $100 \%$ organic in composition, only six violated the assumption of $\mathrm{C}$ content $>40 \%$. The carbon content of these six samples ranged from 30.92 to $39.92 \%$. Carbon content of field samples ranged from 30.92 to $60.71 \%$ with a mean of $51.33 \%$ (Table 3 ). Bulk density ranged from $0.054-0.415 \mathrm{~g} \mathrm{~cm}^{-3}$ with a mean of $0.127 \mathrm{~g} \mathrm{~cm}^{-3}$. The following equation describes $C_{d}$ as a function of $B_{\mathrm{d}}$ calculated from field data in addition to data obtained from literature review (Fig. 2):

$\mathrm{C}_{\mathrm{d}}=B_{\mathrm{d}} \times 468.76+5.82 ; R^{2}=0.95, p<0.001$,

which is slightly below the lower $95 \%$ confidence interval of Eq. (1) (Table 2). Analysis of residuals for the overall data set of 714 field and literature observations indicated increasing variation in $C_{d}$ with $B_{d}$ (Fig. 3). Therefore, a third general equation was calculated from log transformed data which corrected for heteroscedasticity. The simple linear form of the equation calculated from log transformed data is

$\mathrm{C}_{\mathrm{d}}=B_{\mathrm{d}} \times 476.82+4.76 ; R^{2}=0.96, p<0.001$.

The equation calculated from log transformed data is above the upper $95 \%$ confidence interval of Eq. (2), but falls within

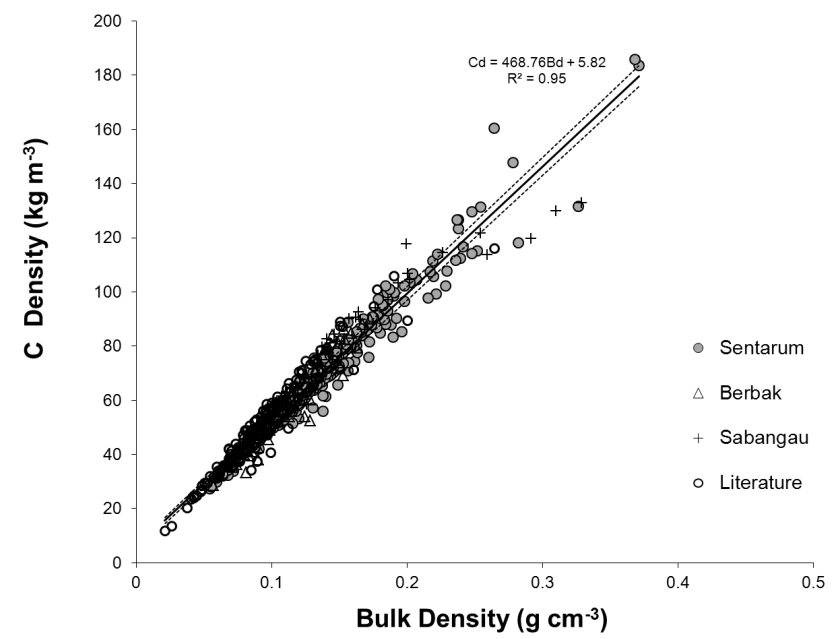

Fig. 2. The linear relationship between peat bulk density and carbon density for 714 data points collected from literature review and three national parks in Indonesia.

the $95 \%$ confidence intervals of Eq. (1). Therefore, Eq. (2) is more conservative than Eqs. (1) and (3) to estimate $C_{d}$ from $B_{\mathrm{d}}$. The tendency of Eq. (1) to overestimate $\mathrm{C}_{\mathrm{d}}$ was apparent for two of the ten transects when comparing estimates of overall peat C stocks (Table 4). Predicted peat C storage was close to mean measured values, and within one standard deviation of the measured means with the exception of Sentarum transect 4 and Berbak transect 1, where the predicted C stocks were 199.54 and $53.66 \mathrm{MgC} \mathrm{ha}^{-1}$ more than the measured mean +1 SD (respectively; Table 4). Sentarum transect 4 was the deepest peat layer sampled, with peat thickness in excess of $12 \mathrm{~m}$. Differences in peat $\mathrm{C}$ stocks estimated using predicted $\mathrm{C}_{\mathrm{d}}$ from Eq. 1 and those estimated using measured $\mathrm{C}_{\mathrm{d}}$ ranged from $0.92 \%-9.57 \%$ (Table 4). The error using predicted $C_{d}$ values was less than $5 \%$ for six of the ten sites.

\section{Discussion}

Guidelines for estimating greenhouse gas (GHG) emissions from agriculture, forestry, and other land uses are provided by the Intergovernmental Panel on Climate Change. The IPCC guidance includes specific details for estimating $\mathrm{C}$ stocks of upland forest ecosystems; however, specific provisions for tropical wetland organic soils and peatlands are lacking (IPCC, 2006, Vol. 4). The close relationship between $\mathrm{C}$ density and bulk density across a wide range of values allows for a reasonably accurate estimation of peat $\mathrm{C}$ stocks for tropical organic soils with $\mathrm{C}$ concentration $>40 \%$ (Fig 3).

The average $B_{\mathrm{d}}$ of all peat samples collected in this study was $0.127 \mathrm{~g} \mathrm{~cm}^{-3}$, which is within reported ranges for other tropical peatlands (see Page et al., 2011). Several published estimates of average peat $B_{\mathrm{d}}$ are considerably lower and of ten closer to 0.09-0.1 $\mathrm{g} \mathrm{cm}^{-3}$ (e.g. Neuzil, 1997; Shimada et 
Table 3. Summary statistics of peat samples collected from three Indonesian peat formations and literature values used to develop predictive models for $\mathrm{C}_{\mathrm{d}}$. Values for $B_{\mathrm{d}}, \% \mathrm{C}$ and $\mathrm{C}_{\mathrm{d}}$ are expressed as mean $\pm \mathrm{SD}$, and values in parentheses indicate the range of observations.

\begin{tabular}{|c|c|c|c|c|c|c|c|}
\hline Peat formation & Sites & Cores & Samples & Depth range $(\mathrm{m})$ & $B_{\mathrm{d}}\left(\mathrm{g} \mathrm{cm}^{-3}\right)$ & $\% \mathrm{C}$ & $\mathrm{C}_{\mathrm{d}}\left(\mathrm{kg} \mathrm{m}^{-3}\right)$ \\
\hline Danau Sentarum NP & 4 & 12 & 433 & $2.1-12.7$ & $\begin{array}{l}0.131 \pm 0.043 \\
(0.054-0.371)\end{array}$ & $\begin{array}{l}50.7 \pm 2.2 \\
(30.9-60.7)\end{array}$ & $\begin{array}{l}65.9 \pm 20.8 \\
(27.2-185.8)\end{array}$ \\
\hline Sabangau NLPSF & 4 & 12 & 96 & $1.9-4.2$ & $\begin{array}{l}0.122 \pm 0.052 \\
(0.059-0.329)\end{array}$ & $\begin{array}{l}54.0 \pm 3.3 \\
(40.4-58.9)\end{array}$ & $\begin{array}{l}65.1 \pm 23.3 \\
(30.1-132.7)\end{array}$ \\
\hline Berbak NP & 2 & 9 & 68 & $4.1-6.4$ & $\begin{array}{l}0.106 \pm 0.028 \\
(0.056-0.172)\end{array}$ & $\begin{array}{l}51.6 \pm 3.6 \\
(40.8-58.2)\end{array}$ & $\begin{array}{l}54.5 \pm 15.2 \\
(28.6-90.0)\end{array}$ \\
\hline Total & 10 & 33 & 597 & $1.9-12.7$ & $\begin{array}{l}0.127 \pm 0.044 \\
(0.054-0.371)\end{array}$ & $\begin{array}{l}51.3 \pm 2.8 \\
(40.3-60.7)\end{array}$ & $\begin{array}{l}64.2 \pm 20.9 \\
(27.2-185.8)\end{array}$ \\
\hline
\end{tabular}

Table 4. Comparisons of peat carbon stock estimates using measured $C_{d}$ and predicted $C_{d}$ using Eq. (1). Estimates are for ten sites across three national parks of Indonesia.

\begin{tabular}{lrrrrrr}
\hline & $\begin{array}{r}\text { Average } \\
\text { peat depth } \\
\text { Site }\end{array}$ & $\begin{array}{r}\text { Measured } \\
\text { peat C stock } \\
\left(\mathrm{MgCha}^{-1}\right)\end{array}$ & SE & $\begin{array}{r}\text { Predicted } \\
\text { peat C stock } \\
\left(\mathrm{MgCha}^{-1}\right)\end{array}$ & SE & \% Difference \\
\hline Sentarum1 & 9.17 & 5709.60 & 956.75 & 6159.01 & 1270.13 & 7.87 \\
Sentarum2 & 6.17 & 3830.00 & 461.36 & 4102.11 & 523.97 & 7.10 \\
Sentarum3 & 2.28 & 1698.61 & 129.34 & 1723.53 & 119.67 & 1.47 \\
Sentarum4 & 12.07 & 7888.88 & 120.45 & 8297.09 & 155.30 & 5.17 \\
Sabangau1 & 2.68 & 1719.09 & 383.55 & 1781.31 & 407.66 & 3.62 \\
Sabangau2 & 2.67 & 1424.61 & 80.23 & 1437.70 & 62.69 & 0.92 \\
Sabangau3 & 3.75 & 2501.16 & 144.83 & 2625.07 & 176.07 & 4.95 \\
Sabangau4 & 3.73 & 2612.55 & 359.14 & 2685.99 & 408.33 & 2.81 \\
Berbak1 & 4.30 & 2252.81 & 66.13 & 2468.46 & 68.46 & 9.57 \\
Berbak2 & 6.32 & 3164.21 & 121.14 & 3227.98 & 114.48 & 2.02 \\
\hline
\end{tabular}

al., 2001; Page et al., 2004; Anshari et al., 2010), and average $B_{\mathrm{d}}$ values of $0.07-0.08 \mathrm{~g} \mathrm{~cm}^{-3}$ are reported from peatlands in Riau and Jambi provinces, Sumatra (Neuzil, 1997; Hooijer et al., 2012). The high average bulk density in this study is likely due to the large number of observations from Danau Sentarum National Park, where $B_{\mathrm{d}}$ averaged $0.13 \mathrm{~g} \mathrm{~cm}^{-3}$. The peatlands in Danau Sentarum are known to be older than coastal peat formations, and higher bulk density with lower total C content may indicate a more advanced state of decomposition (Anshari et al., 2001). However, Neuzil (1997) reported an average $B_{\mathrm{d}}$ of $0.13 \mathrm{~g} \mathrm{~cm}^{-3}$ from a single $6-\mathrm{m}$ thick peat core in C. Kalimantan, similar to the average $B_{\mathrm{d}}$ of $0.122 \mathrm{~g} \mathrm{~cm}^{-3}$ from the NLPSF measured from peat cores ranging from $1.9 \mathrm{~m}$ to $4.2 \mathrm{~m}$ thick in this study. The peat thickness of the Sebangau formation is known to exceed $10 \mathrm{~m}$ (Jaenicke et al., 2008); therefore, lower average peat bulk densities may be expected from this site if a higher number of samples are extracted from intermediate positions throughout deeper peat cores (Page et al., 2004).

Hooijer et al. (2012) reported average bulk densities of $0.073-0.089 \mathrm{~g} \mathrm{~cm}^{-3}$ from several plantation sites in Riau and Jambi provinces using a soil pit method to extract peat cores horizontally to a depth of 1-1.2 m. Neuzil (1997) reported similar average $B_{\mathrm{d}}$ values of 0.079 and $0.083 \mathrm{~g} \mathrm{~cm}^{-3}$ for peatland in Riau using a vertical sampling technique. Although it has been suggested that vertical sampling with a Russian peat sampler can compress peat samples prior to collection, we do not have data to determine systematic bias in our bulk density estimates. Estimates of average $B_{\mathrm{d}}$ for Southeast Asian peatlands indicate a broad range and considerable variation, which is expected considering they cover approximately 21 million hectares throughout Indonesia (Wetlands International 2003, 2004, 2006). Therefore, site level $B_{\mathrm{d}}$ measurements are necessary to accurately determine $\mathrm{C}_{\mathrm{d}}$ and storage.

The overestimation of $\mathrm{C}$ stocks in Danau Sentarum transect 4 and Berbak transect 2 is partly corrected by applying Eq. (2), which includes the complete set of literature and field data points, and is a more precise $\mathrm{C}$ density estimate. Because of the larger sample size and more precise estimate of $\mathrm{C}_{\mathrm{d}}$, we recommend Eq. (2) for rapid estimation of soil organic $\mathrm{C}$ stocks for well-developed peat soils where $\mathrm{C}$ content $>40 \%$ can be assumed. Upper and lower prediction intervals for $\mathrm{C}$ density can also be calculated by applying the $95 \%$ confidence intervals of Eq. (2) (Table 2). Although Eq. (3) corrects for the heteroscedasticity of the data, the model was 


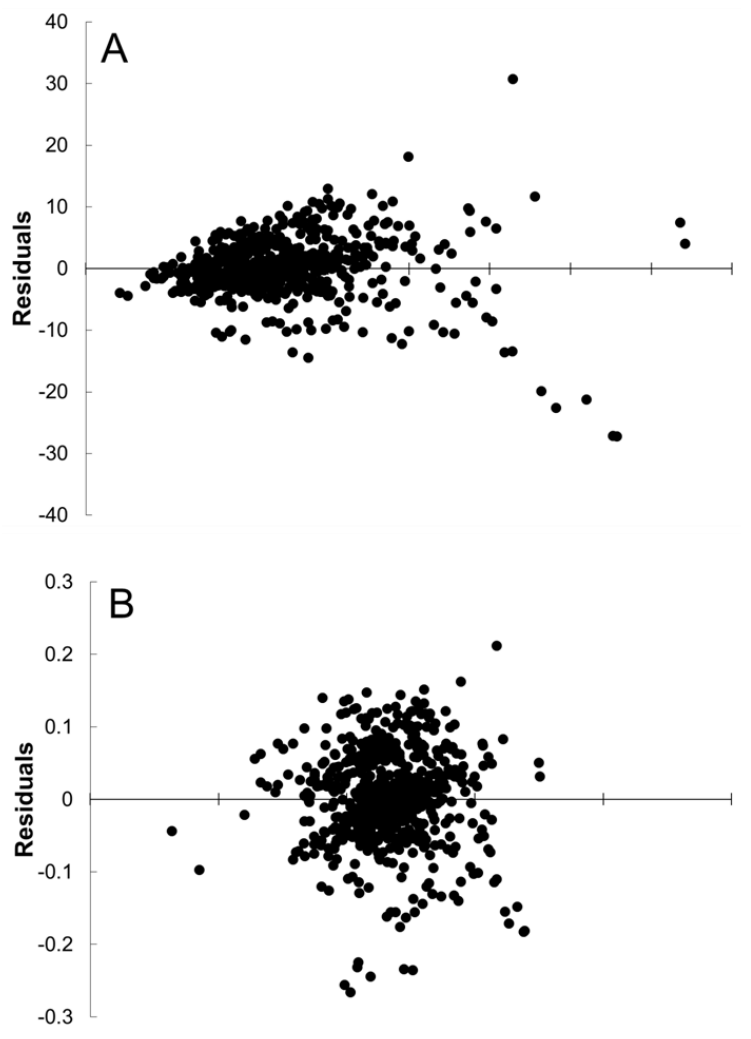

Fig. 3. Residual plots for 714 observations of $C_{\mathrm{d}}$ and $B_{\mathrm{d}}$ from literature review and field samples. (A) Residuals of original data indicating increasing variation in $\mathrm{C}_{\mathrm{d}}$ with increasing bulk density. (B) Residuals of log transformed data.

only slightly improved and confidence intervals were largely reduced. Equation (3) may be a more desirable model if the principle of conservatism does not apply to the estimates.

Direct measurement of carbon concentration in organic wetland soil samples is expensive and requires access to induction furnace elemental analyzers, which can be limited in many tropical remote areas. The equations described here provide an alternative method for calculating organic soil C stocks to partially overcome the economic and technical limitations frequently encountered in less developed countries. These equations are meant to provide a means for rapid belowground $\mathrm{C}$ assessment in tropical peatlands. Similar to other default methodologies suggested under IPCC guidelines, the equations describing $C_{\mathrm{d}}$ as a function of $B_{\mathrm{d}}$ using the complete data set (Eqs. 2 and 3) could be useful for estimating and comparing $C$ stocks in surface peat layers, which are most vulnerable to impacts from fire and land use/cover change.

Current estimates of tropical wetland $\mathrm{C}$ stocks and fluxes often rely on assumed default values for $B_{\mathrm{d}}$ (usually around $0.1 \mathrm{~g} \mathrm{~cm}^{-3}$ ), C content (54-58\%) and average peat depth, despite known variation in all of these variables among peat types and depth profiles of single peat cores (Ballhorn et al., 2009; Jaenicke et al., 2008; Neuzil, 1997; Murdiyarso et al., 2010; Page et al., 2002, 2004, 2011). Average peat depth values probably contribute the most uncertainty to $\mathrm{C}$ estimations, since peat $\mathrm{C}$ storage is scaled volumetrically and values used are often calculated from relatively few samples that may not represent the heterogeneity of peat forests forming under distinct geomorphic, environmental, and biological conditions. Furthermore, substantial quantities of carbon may exist in mineral soils underlying peat layers especially in shallow peats (Murdiyarso et al., 2009). Using Eq. (2) to estimate potential $\mathrm{C}$ storage at a given site could be accomplished by determining the size of the representative area, using peat depth measurements to estimate volume, and obtaining measurements of $B_{\mathrm{d}}$ throughout the peat profile either by vertical or pit sampling. These measurements only require simple peat sampling equipment, accurate sample volume measurements, an analytical balance and a drying oven, all of which can be easily employed in remote settings. Carbon stocks estimated in this way should be considered preliminary in preparation of a more detailed assessment for $\mathrm{C}$ accounting purposes. Initial estimates could then be followed up and verified by measuring $\mathrm{C}$ density directly using a $\mathrm{C}$ analyzer, and more sophisticated three-dimensional spatial modeling of the peat deposit (Jaenicke et al., 2008).

The advantage of using the $\mathrm{C}$ density equations presented here is the possibility of calculating $\mathrm{C}$ stocks empirically without the need for expensive analytical equipment. However, the validity of the $\mathrm{C}$ density equations depends entirely on the accurate assumption that the peat sampled has an organic C content $>40 \%$, which is not problematic for most ombrotrophic fibric and hemic peats in geomorphic settings that preclude allochthonous sources of mineral sediments. Only six of the 597 peat samples obtained from ten sites across three Indonesian national parks in this study violated the assumption of $C$ content $>40 \%$. The equations presented here to calculate $\mathrm{C}_{\mathrm{d}}$ from $B_{\mathrm{d}}$ cannot be used for many organic soils in transitional, floodplain, and mangrove forests, as they are likely to have organic $\mathrm{C}$ content $<40 \%$. Reliable field identification and classification of organic tropical wetland soils is necessary to correctly apply the equations presented, and the assumption of $\% \mathrm{C}>40$ should be validated for a minimum set of subsamples at any given site. Although limited, predicting $\mathrm{C}$ density from bulk density measurements using the general Eqs. (2) and (3) (Table 2) are useful tools for rapid and accurate belowground $\mathrm{C}$ stock estimation for highly organic tropical peat soils common throughout the freshwater wetlands of Indonesia and elsewhere.

Acknowledgements. Funding for this study was provided by grants to the United States Forest Service and Center for International Forestry Research by the US State Department and the US Agency for International Development's Tropical Wetlands Initiative for Climate Adaptation and Mitigation (TWINCAM) project. The authors thank Lou Verchot and two anonymous reviewers for their 
insightful comments and suggestions to improve the manuscript. The authors also thank the local researchers, students, and technicians who participated in the field and laboratory components of this study. In addition, we thank the management and staff of Danau Sentarum, Berbak, and Sebangau National Parks for providing authorization, accommodation and logistical support for the field portion of the study. Peat samples were analyzed at the Bogor Agricultural University, Soil Biotechnology Laboratory.

Edited by: E. Veldkamp

\section{References}

Anshari, G. Z., Afifudin, M., Nuriman, M., Gusmayanti, E., Arianie, L., Susana, R., Nusantara, R. W., Sugardjito, J., and Rafiastanto, A.: Drainage and land use impacts on changes in selected peat properties and peat degradation in West Kalimantan Province, Indonesia, Biogeosciences, 7, 3403-3419, doi:10.5194/bg-7-3403-2010, 2010.

Ballhorn, U., Siegert, F., Mason, M., Limin, S.: Derivation of burn scar depths and estimation of carbon emissions with LIDAR in Indonesian peatlands, P. Natl. Acad. Sci. USA, 106, 2121321218. 2009.

Brady, M. A.: Organic matter dynamics of coastal peat deposits in Sumatra, Indonesia, Ph.D. University of British Columbia, Vancouver Canada, 1997.

Chimner, R. A. and Ewel, K. C.: A tropical freshwater wetland II. Production, decomposition, and peat formation, Wetl. Ecol. Manag. 13, 671-684, 2005.

Donato, D. C., Kauffman, J. B., Murdiyarso, D., Kurnianto, S., Stidham, M., and Kanninen, M.: Mangroves among the most carbon rich forests in the tropics, Nat. Geosci., 4, 293-297, doi:10.1038/NGEO1123, 2011.

Ellison, J. C. and Stoddart, D. R.: Mangrove ecosystem collapse during predicted sea-level rise: Holocene analogues and implications, J. Coastal Res., 7, 151-165, 1991.

Field, R. D., van der Werf, G. R., and Shen, S. P.: Human amplification of drought-induced biomass burning in Indonesia since 1960, Nat. Geosci., 2, 185-188, 2009.

Hergoualc'h, K. and Verchot, L. V.: Stocks and fluxes of carbon associated with land use change in Southeast Asian tropical peatlands: A review, Global Biogeochem. Cy., 25 GB2001, doi:10.1029/2009GB003718, 2011.

Hooijer, A., Page, S., Canadell, J. G., Silvius, M., Kwadijk, J., Wösten, H., and Jauhiainen, J.: Current and future $\mathrm{CO}_{2}$ emissions from drained peatlands in Southeast Asia, Biogeosciences, 7, 1505-1514, doi:10.5194/bg-7-1505-2010, 2010.

Hooijer, A., Page, S., Jauhiainen, J., Lee, W. A., Lu, X. X., Idris, A., and Anshari, G.: Subsidence and carbon loss in drained tropical peatlands, Biogeosciences, 9, 1053-1071, doi:10.5194/bg-91053-2012, 2012.

Intergovernmental Panel on Climate Change: 2006 IPCC Guidelines for National Greenhouse Gas Inventories, in: Volume 4, Agriculture, Forestry and Other Land Use, edited by: Eggleston, H. S., Buendia, L., Miwa, K., Ngara, T., and Tanabe, K., IGES, Japan, 2006.

Jaenicke, J., Rieley, J. O., Mott, C., Kimman, P., and Siegert, F.: Determination of the amount of carbon stored in Indonesian peatlands, Geoderma, 147, 151-158, 2008.
Jowsey, P. C.: An improved peat sampler, New Phytol., 65, 245248, 1966.

Kauffman, J. B. and Donato, D. C.: Protocols for the measurement, monitoring and reporting of structure,biomass and carbon stocks in mangrove forests, Working Paper 86, CIFOR, Bogor, Indonesia, 2012.

Kauffman, J. B., Hughes, R. F., and Heider, C.: Carbon pool and biomass dynamics associated with deforestation, land use, and agricultural abandonment in the neotropics, Ecol. Appl., 19, 1211-1222, 2009.

Kauffman, J. B., Heider, C., Cole, T. G., Dwire, K. A., and Donato, D. C.: Ecosystem carbon stocks of Micronesian mangrove forests, Wetlands, 31, 343-352, 2011.

Lähteenoja, O., Ruokolainen, K., Schulman, L., and Oinonen, M.: Amazonian peatlands: an ignored $\mathrm{C}$ sink and potential source, Biogeochemistry, 15, 2311-2320, 2009.

Langmann, B. and Heil, A.: Release and dispersion of vegetation and peat fire emissions in the atmosphere over Indonesia 1997/1998, Atmos. Chem. Phys., 4, 2145-2160, doi:10.5194/acp-4-2145-2004, 2004.

Langner, A., Miettinen, J., and Siegert, F.: Land cover change 20022005 in Borneo and the role of fire derived from MODIS imagery, Glob. Change Biol., 13, 2329-2340, 2007.

Le Quéré, C., Raupach, M. R., Canadell, J. G., Marland, G., Bopp, L., Ciais, P., Conway, T. J., Doney, S. C., Feely, R. A., Foster, P., Friedlingstein, P., Gurney, K., Houghton, R. A., House, J. I., Huntingford, C., Levy, P. E., Lomas, M. R., Majkut, J., Metzl, N., Ometto, J. P., Peters, G. P., Prentice, I. C., Randerson, J. T., Running, S. W., Sarmiento, J. L., Schuster, U., Sitch, S., Takahashi, T., Viovy, N., van der Werf, G. R., and Woodward, F. I.: Trends in the sources and sinks of carbon dioxide, Nat. Geosci., 2, 831-836, 2009.

Li, W., Dickinson, R. E., Fu, R., Niu, G.-Y., Yang, Z.-L., and Canadell, J. G.: Future precipitation changes and their implications for tropical peatlands, Geophys. Res. Lett., 34, L01403, doi:10.1029/2006GL028364, 2007.

Melling, L., Hatano, R., and Goh, K. J.: Soil $\mathrm{CO}_{2}$ flux from three ecosystems in tropical peatland of Sarawak, Malaysia, Tellus B, 57, 1-11, 2005.

Miettinen, J. and Liew, S. C.: Status of peatland degradation and development in Sumatra and Kalimantan, Ambio, 39, 394-401, 2010a.

Miettinen, J. and Liew, S. C.: Degradation and development of peatlands in peninsular Malaysia and in the islands of Sumatra and Borneo since 1990, Land Degrad. Dev., 21, 285-296, 2010 b.

Miettinen, J., Shi, C., and Liew, S. C.: Deforestation rates in insular Southeast Asia between 2000 and 2010, Glob. Change Biol., 17, 2261-2270, 2011.

Miettinen, J., Shi, C., Tan, W. J., and Liew, S. C.: 2010 land cover map of insular Southeast Asia in 250-m spatial resolution, Remote Sens. Lett., 3, 11-20, 2012.

Murdiyarso, D., Donato, D., Kauffman, J. B., Kurnianto, S., Stidham, M., and Kanninen, M.: Carbon storage in mangrove and peatland ecosystems, Working Paper 48, Center for International Forestry Research, Bogor, Indonesia, 2009.

Murdiyarso, D., Hergoualc'h, K., and Verchot, L. V.: Opportunities for reducing greenhouse gas emissions in tropical peatlands, $\mathrm{P}$. Natl. Acad. Sci. USA, 107, 19655-19660, 2010. 
Nelson, D. W. and Sommers, L. E.: Total carbon, organic carbon, and organic matter, in: Methods of Soil Analysis: Chemical and Microbial Properties, edited by: Page, A. L., Miller, R. H., and Kenney, D. R., ASA Monograph 9, American Society of Agronomy, Madison WI USA, 1982.

Neuzil, S. G.: Onset and rate of peat and carbon accumulation in four domed ombrogenous peat deposits, Indonesia, in: Biodiversity and sustainability of tropical peatlands, edited by: Rieley, J. O. and Page, S. E., Proceedings of the International Symposium on Biodiversity, Environmental Importance, and Sustainability of Tropical Peat and Peatlands, Palangka Raya, Central Kalimantan, Indonesia, Samara Publishing Ltd., Cardigan, UK, 1997.

Page, S. E., Siegert, F., Rieley, J. O., Boehm, H.-D. V., Jaya, A., and Limin, S.: The amount of carbon released from peat and forest fires in Indonesia during 1997, Nature, 420, 61-65, 2002.

Page, S. E., Wüst, R. A. J., Weiss, D., Rieley, J. O., Shotyk, W., and Limin, S. H.: A record of Late Pleistocene and Holocene carbon accumulation and climate change from an equatorial peat bog (Kalimantan, Indonesia): implications for past, present and future carbon dynamics, J. Quaternary Sci., 19, 625-635, 2004.

Page, S. E., Rieley, J. O., and Banks, C. J.: Global and regional importance of the tropical peatland carbon pool, Glob. Change Biol., 17, 798-818, 2011.
Shimada, S., Hidenori, T., Haraguchi, A., and Keneko, M.: The carbon content characteristics of tropical peats in Central Kalimantan Indonesia: Estimating their spatial variability in density, Biogeochemistry, 53, 249-267, 2001.

Taconni, L.: Fires in Indonesia: causes, costs, and policy implications, CIFOR occasional paper No. 38, Center for International Forestry Research, Bogor, Indonesia, 2003.

Wetlands International: Map of Peatland Distribution Area and Carbon Content in Sumatera 1990-2002, Wetlands International Indonesia Programme and Wildlife Habitat Canada, Bogor, Indonesia, 2003.

Wetlands International: Map of Peatland Distribution Area and Carbon Content in Kalimantan 2000-2002, Wetlands International Indonesia Programme and Wildlife Habitat Canada, Bogor, Indonesia, 2004.

Wetlands International: Cadangan Karbon Bawah Permukaan di Papua (Below ground carbon content in Papua), Wetlands International - Indonesia Programme and Wildlife Habitat Canada, Bogor, Indonesia, 2006. 